Science, Technology and Society. An International Journal Devoted to the Developping World (New Delhi, Sage Publications), 4, 2, 1999, 171-204. Translation from French by Nicholas Flay, verified by the author. (Original title : L'histoire comparative des sciences modernes et le contexte de dépendance).

\title{
Comparative history of modern science and the context of dependency
}

by

\author{
Michel PATY*
}

\begin{abstract}
Historical studies on the place of science in the development of nations and in the relationships between the more wealthy powers and dependent countries have succeeded progressively in broadening the field of history of science to embrace situations and problems not previously appreciated. Such investigations can help widen the notion of science in keeping with what is really experienced in practice, by taking in several factors: the actors in science and technology, the contents of knowledge, the context and the social and cultural implications. If these 'differential' research approaches are confronted (involving studies of spatially and temporally well-defined subjects according to discipline, etc.), they provide essential elements for comparative analysis which can trace out the structural features of the diffusion, conjunction and integration of the different sciences. These elements allow us to pick out some significant epistemological problems posed by this rich chapter in the history of science.
\end{abstract}

\section{A BROADER FIELD FOR THE HISTORY OF SCIENCE}

\subsection{A new chapter in the history of science}

\footnotetext{
* Equipe REHSEIS, CNRS \& Université Paris 7-Denis Diderot, 37 rue Jacob, F-75006 Paris, France. Tel (33) 0147030951, Fax (33) 0147030953, E-mail : paty@paris7.jussieu.fr
} 
For some time now the history of science has been enriched by work on the place of science in the development of nations and in the relationships between the rich powers (the 'empires') and their dependencies. Such studies have emerged as a relatively new chapter in the existence of a discipline whose corpus, traditionally, whether dealing with the history of scientific concepts or of the institutions, is largely dominated, at least concerning the modern period (from the XVIth century onwards), by the great avenues of the development of science in European countries, with extension to the USA for the contemporary era.

Interest in these questions directly linked with the research work that was to flourish over a quarter of a century or so, on the history of sciences among what we term the 'developing countries' directly concerned by the main theme, some of which are increasingly prominent on the active stage of science. These countries (Japan is a case apart) are often described as 'peripheral'. The terminology here is rather ambiguous, in that it makes no distinction between a particular economic situation, taken using the world's great economic poles as yardstick, and a state of affairs viewed against a cultural and scientific background: the prevalent implication is that the two go hand in hand. We will discuss later on the notion of 'periphery' to see, in the light of the comparative analysis, to what extent it is appropriate to the viewpoint of the history of sciences.

The burgeoning of this kind of research has come at the same time as a realisation of the importance of the development of science (in education, research and applications) for economic and social progress, and also constitutes an aspect of the conscience of identity in the countries concerned.

In this perspective, the motivation which gives momentum to such research is an important factor, which the preoccupation for historical objectivity must not allow to ignore. It would be interesting to study, from the historiographical angle, the strands which associate such an approach with the socio-economic analyses of the history of sciences in the tradition of John Desmond Bernal, or more generally those of marxist inspiration, and to follow up the various ways in which reflection on this theme has been able to accompany the evolution of political ideas on emancipation and development.

Another source, concerning not so much straight motivation taken in the sense used here, but of the methodology applied (often induced by this motivation), is the sociology of sciences, extended, where it joins up with history, into social history of sciences (it would be worthwhile, here again, to outline the historiographic approach). The social history of science, which is currently in vogue, sometimes to the detriment of the history of its concepts, does not seem, at least from the way it is practised widely in the USA and Britain, to be directly the origin of research into science and the empires, because it is generally restricted to science of Europe and North America.

However, the 'importation' (of social history of sciences) by science historians of 'developing countries' (or the 'Third World'), in the context of their own research on their local situation, has contributed to the definition of the new field and the new objective which are the hallmarks of such research. This objective includes the generation of national currents and traditions in science, the 
interaction between a 'traditional' science and a modern science and other connected issues. Adaptation to this new objective shifts social history of science away from its original orientation, and in particular revealing at once the insufficiency, or even the absence of meaning, of an exclusively social history of sciences.

The question of the contents of science cannot in reality be left in the background. Quite the reverse, it turns out to be fundamentally important in historical studies of this nature, where one cannot stay at the surface of things: here, besides, is another methodological theme, which comparative studies could help to bring out to advantage. All in all, what is known as the 'social history of sciences' thus finds its original role again, as a useful instrument flexible enough to be modified according to the requirements of the subject, but which is far from being sufficient on its own to determine a consistent area of historical research concerning science as a phenomenon.

The interest for this type of research is connected to still another source: the work of researchers which follows a conceptual perspective and bears on the old scientific traditions of cultures and countries which in the past were at the hub of the development of the sciences and which nevertheless today find themselves marginalized. ${ }^{1}$

Research studies on the diffusion, confrontation and integration of sciences concerning the modern and contemporary period, which for brevity we denote 'science and empires', coming from various parts of the world (from the 'Third World' to the 'First World'), have in recent years been the subject of exchanges, juxtapositions and debates which lead to steps toward comparative studies. Available data that show up the differences or that are already in suitable form for comparisons can help to pick out the elements significant for methodology or the conceptual viewpoint, or even to show up new problems for the history of sciences to tackle and which resonate onto the philosophy of sciences. The text that follows focuses on this aspect in an exploratory way with no pretence at being an exhaustive account. ${ }^{2}$

\subsection{Awareness and reappropriation}

First we come back to the question of motives and to that which, as much by the overall insights that such pieces of research can open up, as by their implications on methods and results, perhaps go beyond these, that is to say an intellectual regard on history of sciences and on the meaning of science, or even an 'anthropological project'.

The current preoccupation for the history of sciences and, in a general way, for reflection about science (on its philosophical, historical, social or

\footnotetext{
${ }^{1}$ See, for example, Rashed [1978].

2 To keep the bibliography to a digestible size, the collective works are given in an overall way, with names of authors of contributions cited in the notes where necessary.
} 
political aspects), as far as it can be observed or experienced, is indicative of the function of science in society and in cultural representations. It is connected to the diversity of science's dimensions, visible in the different activities of research scientists who are helping to build it up, of the teachers who transmit it and of those who are affected by it at all levels of life in society. In other words it is concerned with science conceived not only as a body and movement of knowledge, discoveries and memorable reconstructions, but also incorporated in its significance and applications into everyday life, and thus made commonplace in its process and effects ${ }^{3}$.

For access to science to be certain and made with confidence, critical knowledge of this particular science, in its various dimensions, is required. As Benjamin Farrington wrote in his book on Greek science: 'There is no certainty that any human knowledge will not lose its scientific character if only because men forget how it was generated, the questions it answered, and the purposes for which it was created. To a great extent, the mysticism and superstition in educated people is none other than knowledge that has broken from its historical moorings'.4

This living quality, of something non absolute and unfixed, concerns science in its activity as well as its content (its results, its propositions and even its methods). This character is particularly noticeable when we are dealing with the diffusion, reception and incorporation of science as we perceive it today into a given culture. However, this does not for a moment imply a hard and fast relativism, which would dissolve all these constituents into anthropological or sociological conditionments, ${ }^{5}$ or subordinate all possible signification to general philosophical or metaphysical ideas. ${ }^{6}$ It sets itself up only against any dogmatism which would make of what we call science a collection of intemporal truths, and reminds us appropriately that science is the creation of the intellect and human production: but this statement does not exhaust its peculiar nature (what we call science is not just any creation and production, but involves specific subjects and methods).

The question of a definition of science according to its subjects and practices, in time and space, which is inherent to these considerations, is not new in history of sciences, but finds here a new relevance. Must science, as a subject of history, be identified with that which we know today, with approaches and methods which link it to sophisticated technology, to a social organization and recognition, to its systematic transmission through teaching and diffusion ? For the modern period itself, the fact that research has been conducted individually far

\footnotetext{
${ }^{3}$ Cf. Paty [1990].

${ }^{4}$ Farrington [1944].

${ }^{5}$ See the essays by Paul Feyerabend, some of the notions of Thomas Kuhn, the work of various 'relativist' schools of sociology or history of sciences, such as Edinburgh's, or the one represented by Bruno Latour, etc. For some critical points, see Paty [1996c].

6 The physicist Erwin Schrödinger, for example, interpreted Benjamin Farrington's comment, already cited, in this way, with the following remark: 'All science is bound to human culture in general, and scientific results, even those which appear at a moment the most advanced, the most esoteric and difficult to understand, have no meaning outside their cultural context' (Schrödinger [1950]).
} 
from the main centres is a pertinent reminder, one of the fundamental dimensions of science, as attitude or turn of mind, guided by reason, even where there is no systematic plan, particular concern to formalize, or to display technology in putting it into action, indeed even with no particular claim to originality.

Clearly it would be absurd to refuse to call 'science' the act of acquiring knowledge with the sole aim of knowing, science as a daily effort to understand the world, without the present-day facilities. Moreover, any learning, even incorporated in collective representations and social practices, maintains a relationship with what we understand by knowledge, and therefore with science taken in its most general sense. In consequence, it is reasonable to admit that no culture and no country in the world is stranger to the history of sciences, when this is viewed according to the wide acceptation which in turn embraces it in terms of one or other of the dimensions that we attribute to it today. 'Science', under this wide meaning has been, and still is, in all likelihood, a possible condition of that science taken in the narrower sense prescribed by today's standards.

The history of sciences, which came into being along with the development of the whole complex of contemporary sciences, has often limited its field of vision to the narrow acceptation of the science it knew, before broadening gradually its perspectives by taking into account the great variety of systems of representations of the world and of thought depending on the civilisation. As much as to say, to loosen itself from the prejudices that led it to misconstrue some real works of science which lay off the beaten track. "The history of human efforts to understand his natural environment (remains, essentially), an untold story", often as heroic as that of recognised and famous successes, Marcos Cueto quite rightly reminds us. It is only by token of such a widening of vision that we can get nearer to a realistic conception of what science is. The considerable mass of new data which are thus incorporated to not only provide a corrective to 'mainstream' history of sciences, as these data can prove to be qualitatively highly important for certain chapters, and the comprehension of their own significance can lead us to cast a different eye, renewed and more up to date, on science and its universality, of which these chapters are a constituent part. $^{7}$

\subsection{Countering omissions from the historical memory}

Awareness of a more binding dimension of the history of sciences necessary for the latter to be better grasped, relies on a twofold refusal: refusal to be set aside from the movement that makes science, and refusal of oblivion from the historical memory. Scientists from the Third World who are undertaking the updating of whole segments of history of sciences which were not taken into account or hitherto ignored for some reason or another, are often motivated by the keen sentiment of the dignity of the culture from which they originated, linked to

\footnotetext{
${ }^{7}$ On the question of the universality of sciences, see Paty [1997, 1998].
} 
a legitimate search for the intellectual and social identity, which requires recognition of their own roots. This frame of mind is certainly no stranger to the initiative taken in 1987 by the Third World Academy of Sciences to establish a history of sciences prize aiming to reward "the best piece of research that sheds light on the work of a scientist form a Third World country whose results had passed unnoticed"8. Although the prize is naturally destined to reward excellent work by a historian, and not the scientist whose work has been unearthed, it is the field of study which is given value here, with attention brought to some remarkable scientific discoveries and achievements, not only in the ancient and classical times, but also in the past few centuries, in order to preserve this humanity's heritage and contribute to restoration, enlargement and universalization of the collective memory on the sciences. ${ }^{9}$

There is indeed much pioneering work which has long been ignored by history of sciences practised from the viewpoint of the 'centre'. Several candidate essays for the TWAS history of sciences prize focused on such cases, such as that of the Argentinian palaeontologist Florentino Ameghino or Dr José Ramirez, the 'father of botany in Mexico', or again the notions and efforts of Digamber Mitra in his fight against malaria in Bengal in the mid XIXth century or, once more concerning India, the personality and achievements of the mathematician Srinivasa Ramanujan (1887-1922). ${ }^{10}$ The history of technologies would provide examples as well. ${ }^{11}$

The comptence alone of historians of science without the right motivation would probably have remained blind to the rich value of this field. Conversely, motivation which is not accompanied by the necessary competence would be uninteresting, and even harmful if it took its ideological preferences as proof criteria or standards of judgment to the detriment of respect for the facts, as has often been seen in history.

\subsection{An anthropological project?}

The question of 'motivation' can also be framed in another way, enlarging it by a kind of secularization of any inherent ideology, to set it in relation to an 'anthropological' dimension found in this type of research, in a sense akin to that claimed by George Sarton in the introduction to his History of science. ${ }^{12}$ This American historian of science explained that underlying his work there was an 'anthropological project'. He describes this as follows: in the same way that science reveals the unity of nature, the history of science reveals the unity of science, thus providing evidence for the unity of humans, in such a way that the

\footnotetext{
8 The Third World Academy of Sciences (TWAS), founded in 1983, with headquarters in Trieste. This prize is awarded biennially : see the document drawn up by TWAS [1990].

9 Cf. TWAS [1990].

10 See respectively the contributions of G. A. Canziani and C. E. d'Attelis; of H. F. Olvera and H.

O. Booth; of de Sarma Sunil Sen; of Srinivasa Rao at TWAS [1990].

11 On this aspect, see Gama [1979, 1987, 1993].

12 Sarton [1931].
} 
history of science is essential for man, in the scientific age, in allowing him better to comprehend his situation in the cosmic evolution. One will perhaps find the project thus set out dependent on a linear, positivist and scientistic, conception of science and progress, marked at the time, when, as an effect, chaos was threatening civilisation, if darkness of the mind and the barbarity represented by nazism were to prove victorious.

At least the idea will be retained of a relation between one of the dimensions of history of sciences and our concept of civilization. The fact of including in the history of sciences the field that interests us here in this respect takes on a clearly evident anthropological dimension, seeing that it is a question of understanding better the relations between science, culture in the widest sense of the term, and development. This project corresponds to a more open conception of science as a subject for historical analysis, from which can be expected the formulation of new methodological requirements, where what we call science would be tackled in an overall, integrated way, going beyond the fragmentary and reductionist approaches which led to miss crucial aspects of it.

Perhaps then it will be possible to reconsider the questions that, in a scepticism fuelled by criticism of appearances and by the twists and turns of history, it was believed necessary to leave aside, on the idea of advancement of scientific knowledge and on the possibility to talk of world civilization.

\section{FACTUAL KNOWLEDGE AND THEORY BUILDING}

\section{1. Case studies and elements for analysis}

The already numerous pieces of work on the history of the diffusion, confrontation and integration of modern sciences in local cultures appear on the whole as just so many case studies concerning specific conditions of geography, time and disciplines. Such data, either factual or already bearing some elements of interpretation, are clearly essential before any attempt at even any partial explanation can be made. They form the basis from which it is possible to discern topics and frame questions. The specific nature of situations precludes generalization extrapolated from any one of them, for such a generalization would be highly arbitrary.

In his comparative studies on the periodization of mathematics, notably Arabic ones, and on the transmission between different traditions, Roshdi Rashed has emphasized the degree to which all-embracing conclusions cannot be proposed (for example, on a science considered as a whole entity), but only 'differential' ones, concerning distinct and specific parts of these sciences. About periodization, he states that 'only a differential kind of division can take account of historical facts in themselves'. ${ }^{13}$

Only by 'differential' studies, whose subject is restricted but which are accurate and varied, concerning different but in some respect comparable

\footnotetext{
${ }^{13}$ Rashed [1987].
} 
situations (this is indeed the original meaning of the term differential: different but very close), comparative statements can legitimately made. It is with these differences and these similarities as starting point, situated exactly, that appropriate concepts and categories can be formulated, that could clarify the facts, understand them in their own reality and broaden the field of investigation which corresponds to them.

Such is, from the straightforward point of view of the history of sciences and of its methodology, one of the fundamental elements at stake in comparative research on the diffusion and integration of sciences. It is an epistemological stake, which guarantees that reality of these questions can be tackled, in other words the very substance of the historical approach. The subject is relatively new, having up to now been left aside both by historians and, as has been said, by historians of science in their preoccupations. Research work has greatly increased since the pioneer studies by Roy MacLeod on the British Empire and 'imperial science'14 and the (relatively) many studies on the history of sciences in the Third World which dwell on this topic in relation notably to Japan, Korea, China, India, Latin America, Iran, Turkey and Egypt. ${ }^{15}$ The different works in question have, over the past few years, been the subject of publications, regional meetings and international symposia ${ }^{16}$ and already lend themselves to comparative investigation. ${ }^{17}$

Later on we will broach some of the themes that stand out from these studies. We will ask ourselves, before we come to it, what kind of theoretical persepctive the study of facts of this nature permits. Is it a question of erecting theoretical models about the historical conditions of development or, more correctly, of formulating proper concepts and categories for this field of study, and accompanying them as well by the criticism of general categories or concepts already existing?

\subsection{Concepts and categories}

\footnotetext{
14 MacLeod [1982].

15 Among the great amount of works on history of sciences on a country or region, some of them individual, most of them collective, let me mention the most recent ones brought to my attention, in addition to the books and articles to which we shall refer further on: for India, Rahman [1984], Kumar [1991; 1995], Sangwan [1991]; for Turkey and Moslem countries: Ihsanoglu [1992], Rashed, article in Alfonso-Goldfarb \& Maia [1996]; for China : , Jami, Hashimoto \& Skar [eds., 1995]; for Latin America: Lafuente \& Saldaña [1987], d'Ambrosio [1989], Calderon et al. [1992], Lafuente \& Catala [1992], Quevedo, Vasco, Obregón \& Orozco [1993], Motoyama [1994], Vargas [1994], Alfonso-Godfarb \& Maia [1996], Hamburger, Dantes, Petitjean \& Paty [1996], Arboleda \& Osorio [1997], Ferraz [1997].

16 We can mention in particular the Seminar on science and empire, held at New Delhi from 21 to 23 January 1985, on the initiative of Abdur Rahman; the international symposium Science and empires, organized by the REHSEIS team of CNRS, which was held at UNESCO, Paris, from 3 to 6 April 1990 (see Petit jean, Jami, Moulin [1992] and, for the essays in the form of unpublished manuscripts, Science et empires [1990]), the Symposium The sciences beyond the West, organized, under the aegis of ORSTOM at UNESCO in 1996 (see the seven volumes of proceedings, Waast [1996]), and the memorial symposium for Joseph Needham which took place in New Delhi in 1996 (Habib and Raina [1998]).

17 See the preceding references and Habib \& Raina [1998].
} 
The question of the spread of modern science stimulated very early on theoretical approaches which sought to generalize, no doubt because of its most obvious stakes, like development, at which this spread pretend to beaimed, or the nature of imperialism, in the context of which it was operated. But is it the best, or even the only way to 'understand' the issues that diffusion and integration of sciences raise, to straight awa put forward global interpretation models ? Are such models, some of which are advanced before even a sufficently sound factual base has been established, and often arbitrarily elaborated following the pattern of quantitative sciences, even in the best of cases not schematic and reductive ?

We could start by asking about the meaning of 'understand' the kind of 'subject' considered in these questions. It signifies, to find, among the diverse cases and situations encountered, some perspective which illuminates them, which favours close comparison, which allows similarities to be spotted. Conversely, differences can be situated for facts that are in certain respects similar, to recognize relationships that give consistency, or even causal links, and to relate these circumstances to other factors, known through other means. It means first and foremost a comprehension of facts, far from any abstract scheme of organization conceived before them, if not independently, and it requires as first basis the variety of data provided by case studies, differential or even already comparative studies. This comprehension functions by elaboration of suitable conceptual instruments, thought out according to these facts, and whose purpose is to forge a path through them and to detect significant points. Comparative studies that do exist (although still few in number) have already picked some out, as we will see in what follows, after a rapid critical recall of the question of 'models'.

\subsection{A critical look at the proposed models}

Explanatory models for the diffusion and integration of sciences could, in principle, stimulate means of understanding all the factual data; it would then be legitimate to talk of 'good use and sound criticism of the models', rather than confront them straight away with a negative attitude. On examination, the drawbacks by far outweigh the advantages, so that 'good usage' of models suggested remain highly problematical.

The 'diffusionist' model advanced by George Bassala has the undisputable advantage of being chronologically the first; ${ }^{18}$ this is why it is the one most often mentioned. However, it also has the merit that it can be refuted: this makes it valued as a subject for examination in this area of historical studies. The scheme was in vogue for a while but soon began to show its limitations. It is an Americano-centric view and assumes, somewhat naïvely, that any scientific development in a given region of the world must essentially follow a pattern of progress involving threee successive stages, in order finally to become endowed

18 Bassala [1967]. 
with the configurations and values of Western science considered as the norm. This 'growth law' was cast in the mould of the evolution science is presumed to have experienced in the United States (considered an obvious example of success). The first stage is thus one of 'science-exploration' (exercised by scientifically-oriented travellers, for example), which gives way after a time to 'colonial science' (dependent on the metropolis), a necessary second phase which prepares the ground for the final stage of the metamorphosis, an autonomous science which then emerges, like a butterfly that springs from the chrysalis.

In setting the local science under study apart from the prevalent economic, political and cultural context in which it evolved, the model described commits the error of applying too intellectual an approach. Stressing as it does the process of diffusion only, as if science were to enter a vacuum, it ignores the conditions in which it was received. ${ }^{19}$ The latter can vary enormously depending on whether the host was one of the 'new countries' where European societies had been transplanted, such as the United States, the Argentine or Australia, or societies which had a scientific tradition, as in the cases, themselves very different, of Ottoman science which had contacts with the West, or that of Egypt or Japan. Or again there could be the emergence of modern science at national level as occurred in India in the period 1876-1920.

The relationships between Ottoman science and European science, for instance, cannot be reduced to any standardized notion of a colonial science. Such links indeed existed over nearly five centuries and were not maintained by an allembracing European Science but turned on certain aspects of particular sciences, which varied with the period and the interests of the moment. No more is the idea of 'colonial science' appropriate in the case of India, ${ }^{20}$ where the blossoming of a national science cannot have originated from an embryonic stage of this kind, if only for the fact that the initiators of the first phase are not the same as the 'guardians' or the 'soldiers' who promoted the second, the latter including nationals of the country as much as foreigners (who came in the wake of the colonial power, but having at heart the development of a system of education and science adapted to the host country's interests).

In a general way, the dynamics of the installation of a truly national science can only be understood in the light of local intellectual, cultural, social and economic conditions. It appears, in all the cases studied, that for a science to mature, an explicit and effective will to further a national science is required.

The model, or rather a conception of types of situation, suggested more recently by Lewis Pyenson to take account of the diverse expansion strategies relative to the exact sciences has the advantage and the drawback of being a simplified picture built up using few parameters. The author selected three in order to describe the nature of these strategies, each parameter brought in according to a particular approach. ${ }^{21}$ There is the 'mercantile' approach (a line

\footnotetext{
19 Inkster [1985], P. Crozet, contribution in Petitjean [1996] and in Habib \& Raina [1998]; contribution by MacLeod and by Krishna in Petitjean et al. [1992].

20 Concerning this notion, see Reingold \& Rothenberg [1987], Krishna (contribution to Petitjean et al. [1992]); also the articles in Lafuente \& Català [1992] and in Petitjean [1986].

21 Pyenson [1985a, 1992]. See also Pyenson [1985b, $1989 \mathrm{a}$ and b].
} 
attributed to Canada or to Belgium, for example), where the leading players are like traders, serving the the economic interests of organized Companies, who look on scientific research only in terms of immediate utility. Then the 'missionary' approach (according to Pyenson, this is the case of the French approach) brings together 'civil servants', who take on the various aspects - political, scientific, religious even - of their office, without great concern to develop research, and acting exclusively in the interests of the metropolis. The third strategy is the 'scientific' one (Germany is taken as a perfect example) where the lead players are scientists, have more freedom and are more devoted to research. Other than these clear-cut cases, hybrids can be identified: the United Kingdom for instance is associated with the latter two strategies, the Netherlands is seen to have taken all three approaches.

The immediate limitations of such a typology can clearly be seen. The first, intentional and claimed by the author, is to consider the development of colonial empires only under the angle of the use of sciences, restricted besides to the exact sciences. The second is to confine examination to European science and to its immediate agents, without viewing either the local conditions where the science might be received or the prevalent traditions. The third is relative to the agents or vectors of the expansion strategy, dealt with indiscriminately as a single entity, whereas some very different, and not necessarily coherent, levels of involvement should be distinguished, of the State or government, of the administration (colonial and metropolitan, which are themselves distinct), and of some remarkable individuals, more or less closely linked to explicit strategies. A fourth weakness of the analysis is perhaps more serious. In this description of the lines taken towards expansion, the strategic intentions of imperial powers are not taken into account, whereas these could well throw into proper perspective the apparent neutrality of strategies aligned with the scientific approach proposed in the model. The latter could thus more certainly mask the imperialist nature of the enterprise (and the history researcher could be caught out here). ${ }^{22}$

However, what really interested Pyenson, rather than a characterization of the ways in which imperialism exerted its influence, is to show how the practice of exact sciences (which he distinguishes form that of descriptive sciences, by inspiration from Kuhn's analysis) continues unscathed by strategies or ideologies, and how it corresponds to the good side of a Western mission of civilization which would remain stamped with idealism. ${ }^{23}$ Although his choice of the exact sciences is understandable in this perspective, they do not clearly constitute the sensitive indicator that would provide general conclusions about an expansion strategy. The sciences directly useful for the ends of colonization or domination like biology, medicine, meteorology, geography (associated with astronomy), and those linked to prospection for resources, such as geology, and mineralogy, are in

\footnotetext{
22 The nomenclature for the expansion strategies proposed by Pyenson, and the conclusions he draws from them, already discernible at the start when he chose it, is not free of received ideas and prejudices and sometimes is a reflection of conventional imagery.

${ }^{23}$ Palladino \& Worboys [1992]. I refer to this welcome criticism of Pyenson's model, although I do not share the authors' support for theories of the 'social construction of science', the extreme aspects of which they do not seem to reject.
} 
contrast excellent for revealing the different forms these strategies take, as the case of the British Empire in India well illustrates. ${ }^{24}$ Other case studies have also induced criticism of this typology, ${ }^{25}$ which will at least have given the opportunity to go deeper into certain aspects of transplantation of European sciences.

A category of 'world science' was advanced by Xavier Polanco, ${ }^{26}$ but no real associated model was constructed. Its aim was to take into account flexibly and quite generally all the complexity and variety of social and cultural factors intervening in the historical relatioships between science and development. Polanco defined it, by analogy with the 'world economy' of history according to Fernand Braudel, as a worldwide system of science organized around a 'centre' (which shifts in the course of history), encircled by two peripheral zones: a semiperiphery and a periphery. This construction of the international network of science would respond to both short-term rhythms (corresponding to the usual succession of circumstances) and to others of longer 'wavelength' (those of historical time), and would determine two different time-scales for analysing the 'world science' configurations and the diverse strategies of expansion.

\section{SOME CONCEPTS REVISITED}

Examination of attempts to situate historically the diffusion and integration of sciences rapidly reveals how imprecise and sometimes inadequate are the contents of generally accepted concepts described with some of the words employed, like 'expansion', 'strategy', or 'periphery', but also the very term 'science' itself. The word 'expansion', for example, covers many different meanings which would describe different levels of reality. The problems posed are not the same if the word is taken to signify the 'development of knowledge and its dissemination', or to denote a relationship of domination, primarily economical and political, from the centre out to the periphery. The word 'strategy' corresponds to its usual definition only if it means a project with an underlying deliberate intention; but it is often, and wrongly, used to mean 'configuration' or 'pattern' or 'tendency', in a purely descriptive way, not necessarily with any presupposition in mind of planning or a thought out strategy.

\subsection{On the definition of science}

The very notion of science deserves to be reconsidered, in several respects. One aspect concerns the enrichment of our idea of science with the historical realities encountered in the countries considered to be on the 'periphery'. Science, as movement of knowledge, cannot be identified either with its organization or

\footnotetext{
${ }^{24}$ Worboys [1979], Kumar [1991, 1995], Palladino \& Worboys [1992], etc.

${ }^{25}$ In particular, see articles by Chikara Sasaki and Togo Tsukahara dealing with relations between Japan and the Netherlands in the early XIXth century, respectively in Petitjean, Jami, Moulin [1992] and in Sciences et empires [1990].

${ }^{26}$ Polanco [1992] and article in Petitjean et al. [1992].
} 
with its applications, and the development of science is not to be confused with technological or industrial development, nor for that matter with economic and social development. The visible paths of present-day science in the 'First World' do not constitute the norm for what can legitimately be called 'science'. It appears, as a consequence, that historical research on the diffusion and integration of sciences must focus on both questions of the content of science and institutional, economic, socio-political and cultural factors. The difficulty is (although it is a general problem of methodology in the history of science) to bring these two sides together in an appropriate way: science as a body of contents (and active development of these contents), and as an activity and fact in society. That is only possible through case studies (still rare for sciences in the Third World), like those dealing with the different styles of practising science (in all the subject areas tackled by epistemology and the history of sciences) ${ }^{27}$, scientific traditions and confrontation between them. ${ }^{28}$

When we talk of science, we have to specify straight away to what branch we are referring. The difference between the exact and the human sciences is fundamentally important here. ${ }^{29}$ However, even if we stick to the natural and exact sciences, individual cases are highly different according to whether we are investigating mathematics, mathematical or theoretical physics, or chemistry, geology, mineralogy, botany or zoology, even paleontology; the same evidently goes for medicine and pharmacology. Distinction should be made between pure and applied sciences. As for technical spheres or technology, they form still another separate area, with their own internal demarcations. Each of these branches, each of these areas of what we conventionally call science (or technology) corresponds to conditions created by education and training, traditions, development, or in relation to socio-cultural pressures and influences, very different in character.

\subsection{The periodization of science}

The meaning given to the word science is also bound up with the problem of periodization, the arrangement in chronological order of scientific activities and works in line with certain great periods or phases that are identifiable. To exemplify, we can sketch out roughly a succession of periods for the sciences as a whole, by defining the reference time sequence for modern and contemporary science (because a specified angle of approach must always be adopted ${ }^{30}$ ). The sciences of Antiquity are omitted in this case.

The first phase consisted of the science cultivated around the Mediterranean fringe from the IXth to the XVIIth century in the Middle East and

\footnotetext{
27 See Paty [1990], chap. 4 (1996b].

${ }^{28}$ Several were put forward in Science et empires [1990].

29 See later on.

${ }^{30}$ For a discussion on the choice of an angle in relation to the possibility of talking of universality, see Paty [1997, 1998].
} 
Europe, commonly called 'classical' science, ${ }^{31}$ which is the direct ancestor of science of the modern world, although it has been long underestimated. Also attachable to this period are the so-called traditional sciences which had blossomed in other areas like China, Japan, ${ }^{32}$ or India, and which have also contributed to the development of modern science, even though in more indirect ways and using sets of methods yet to be adequately elucidated.

Pre-Colombian sciences raise special problems, seeing that they developed out of contact with the classical and traditional sciences already mentioned. Also, they were destroyed along with the Amerindian civilizations that fostered them, and therefore largely elude any attempts to learn about them. ${ }^{33}$ It is justified, however, to place them in the first period, as 'Pre-Colombian sciences', in parallel with the classical Mediterranean science and traditional Eastern and Far-Eastern science. As for 'indigenous' learning (like in Africa, the Americas or Oceania), often incorporated de facto in modern science, they form a case apart. They should by no means be neglected.

The second period is precisely that of 'modern science' (European, or Western), which goes from the XVIIth century in Europe up to the preent, or at least until the Second World War, if a third period is to be reserved for contemporary world science and its great changes. Marked by the setting forth of several areas of scientific investigation, by the preoccupation for applications and establishment of a direct relationship from science towards technology, and by the constitution of an institutional organization, this period is at the same time one of modification of the notion of science. This is conceived increasingly in terms of a united whole, accompanied by the idea of advancement of knowledge by accumulation, and by a philosophy which, in its diversity, is laid out following certain distinctive lines and themes, objectives and debates, and which are symbolized by the names Galileo, Bacon, Descartes, Newton, those of the great thinkers of the Age of Enlightenment, then Kant, Comte, Marx, Spencer and others.

The third period, the contemporary phase, which stretches from the Second World War and continues today, is that of the 'globalization' of science. A direct extension of 'modern science', it can, however, be distinguished from it to throw into relief the changes that have taken place not only in the practice of science (like research, education, applications) but also in its conception,, with the emergence of 'technoscience'. In this the institutionalization of scientific activity is systematized and a new approach to scientific research is deployed, almost industrial in scale and backed by substantial financial means and technologies, the 'big science' (with nuclear and particle physics, astrophysics, molecular biology etc.). Scientific knowledge, spread around the globe, is linked more directly than ever to its applications in technology (notably now with biotechnologies), including the effects on everyday life and on the environment.

\footnotetext{
${ }^{31}$ Rashed [1987], Saliba [1987].

32 Nakayama [1987].

33 On local techniques in Pre-Colombian America, see the special issue of the journal Quipu [1992].
} 
Such periodization concerns world history of science considered from the starting point of our present-day vision; other publications, more localized, have been advanced to describe the nature of history of sciences in a given cultural zone, or the history of relations or contacts between a traditional science and modern science. In China, for example, the transfer of modern science happened by different means of diffusion and reception in the two eras which saw liaison with the West, in the XVIIth and XIXth century respectively. ${ }^{34}$

\subsection{Ambiguities in the notion of 'periphery'}

The notion of 'periphery' is often used to take account of the specificity of the current situation in countries situated far from the centres of development and depending on them, and it is often accepted as self-evident that it also applies to science and its history. However, it concerns rather the present structures of science and technology in the countries considered (those of our third period and the end of the second), in their relation to the system of economic production in the capitalist developed countries. The limits of this notion appear as soon as one starts delving into the history and evolution of different countries' scientific disciplines and institutions, which require a focus on the specificity of each scientific field, on the reality of interactions and exchanges, on the diversity of contributions and attention also to differences between disciplines, and it is applicable more to static situations. 35 !

Moreover, it is preferable to make a difference between 'peripheral science' and 'science in the periphery'. ${ }^{36}$ The first would be marginal in terms of knowledge content and results, quality and quantity, as well as with regard to the scientific, education and industrial system. The second allows us to escape from such a tightly defined set of problems. We could thus admit the possibility that major contributions to science can indeed originate from the so-called periphery, or that scientific training can reach a comparable level to that achieved in the countries of the 'centre'. It also lets in the possibility of taking account of differences in this same 'periphery' (in the politico-economic sense), where it happens that advanced sectors of research or production coexist with a global situation of backward development or social marginalization, as observed with Brazil, India or Pakistan. In addition, the 'periphery' itself varies and does not have the same meaning at different times in the course of history. Some cultures which were at one time central have become peripheral (like the 'classical' sciences conducted in Arabic in the Moslem countries)

Concerning the great civilizations which have developed in parallel, whether or not they have interacted in any way, the term 'periphery' is meaningless, at least at global level; but we can still consider the zone of direct influence radiating from one of these cultures taken from the local point of view. The word provides no assistance in attempts to characterize pre-Colombian

\footnotetext{
34 See the contribution by Catherine Jami in Petitjean et al. [1992].

35 See, in particular, Mac Leod [1982], Dias, Texeira \& Kessurs [1983], Vessuri [1987].

36 Cueto [1989], p. 28.
} 
civilizations by comparison with European science of the classical and modern periods. With regard to scientific achievements, the situation prevailing in the Americas from the colonial period to the XIXth century (and in some cases this persisted into the early XXth) would not be adequately represented by opposing a 'periphery' and a 'centre'. The differences in the work and the profile of scientists were not so marked. Research was less demanding in terms of financial means, books and instruments were available. Also travelling and exploring scientists toed and froed between the two situations; and this is not to mention the emigration of scientists and engineers and the transplantation of micro-societies originating from Europe (as for example in the case of Argentina) which favoured the continuity of exchanges. ${ }^{37}$

Even when it remains legitimate, in regarding a recent period of time, to talk of the periphery, that by no means signifies that all science practised on the 'periphery' is 'peripheral'. Some remarkable pieces of work are to be found there, which are just as good as any studies originating from the home countries. There is a long list of them: from the microbiological research of the Brazilian Oswaldo Cruz at the beginning of the century, ${ }^{38}$ work on endocrinology of the Argentinian Bernardo Houssay ${ }^{39}$ which earned him the Nobel Prize in 1947, or studies on high-altitude physiology in Peru, ${ }^{40}$ to the discoveries in India, by physicists Chandrasekhara Venkata Raman and Satyendra N. Bose, and to the achievements in Japan of the school of nuclear physics, from Hantaro Nagaoka to Hideki Yukawa and Shinishiro Tomonaga. This is not to include the contemporary period where such cases have increased in number enormously and exchanges are more frequent. (It would be interesting, furthermore, also to consider for this recent period important work effected by scientists originating from the 'periphery' in the scientific laboratories and institutions of the developed 'First World'). What is true for scientific discoveries is also valid, in a certain number of cases, for the production of technological advances (medicine is a particular field that occupies a special place between the two).

The idea of 'periphery' applied to scientific knowledge, even only implicitly, has a perverse effect on the objectivity of the dominant picture of science which is presented. The distortions in images of the past are extended onto those of the present, which a quick look at a weighty instrument like the Science Citation Index will ascertain. This directory eliminates straight away from its statistics most publications which do not belong to the recognized circle of those that produce scientific knowledge, defined according to criteria that favour industrialized countries, and even the English-speaking ones. ${ }^{41}$

\subsection{Remarks on human and social sciences}

\footnotetext{
37 See Paty [1992b].

38 Stepan [1976]. Literature on the subject is also pertinent, with the fine novel by Moacyr Scliar on Oswaldo Cruz (Scliar [1992]).

39 On Bernado Houssay (1887-1971], see Fogli [1971].

${ }^{40}$ Cueto [1989].

${ }^{41}$ See Gaillard [1989].
} 
The bodies of work considered here concern essentially the exact and natural sciences. However, the human and social sciences, which have a different history, would also offer very useful information under the point of view dealt with here. The concepts and theories adopted are often suspected to be imported or adapted, and to be dependent on European and North American works and institutional centres: elaborated to fit a different context, they would be out of phase with the real situations found locally and would bear the mark of alienation. The question under discussion is then to know what part conditions reflecting local situations and that of more general considerations play in the choice of subjects and theories for the social sciences.

In contrast to the exact sciences, the human science or social science researcher is involved in his study subject. And this subject, like the theoretical points it induces, is generally dependent on the social context of the time. Even when they were in the making, which is recent because they began using scientific criteria in the XIXth century, these sciences owe much to data collected in the colonized or dependent countries and to reflections which went along with their collection, themselves dependent on information gathered from local cultures. In a general way, the dependence of the context of research in this area, for example on the choice of subject for investigation and the manner of formulating the problems and of interpreting them, can turn out to be positive for originality and creativity, not only a factor that tends to alienate.

Maria Isaura Pereira de Queiroz has shown this eloquently for anthropological and sociological work done in Brazil in the XIXth and XXth centuries, analysed in relation to socio-political contexts of their respective historical times. The salient work by Gilberto Freyre on the sociology of the patriarcal Nordeste region, or of Caio Prado Jr on the history of social struggles in the heavily industrializing area that was the State of Sâo Paulo, are just the tip of a whole body of work which goes back nearly a century. ${ }^{42}$ More obscure, these pieces of social sciences research on that country have laid down an original resource, rich in empirical data but also in points lending themselves to theoretical interpretation borrowed to particular need (thus diversifying the influences) from recognized authors from the home countries, their contemporaries, whose names are milestones in the progressive building-up of these sciences. In such a way that, when the social sciences began to be taught in the newly-founded universities in Brazil, from the 1930s, visiting professors from abroad found in front of them audiences already prepared by dint of their readings of work that represented a century of local research. ${ }^{43}$

In Europe, the budding social sciences followed a course which went from indoor reflections on theory to the study of empirical data. In Latin America the reverse happened. Owing to researchers' situation in their environment, they started by empirical investigation, without the inhibitory influence of

42 Queiroz [1989].

43 Among these lecturers contracted in from abroad (especially from France for the human sciences) were Roger Bastide, Paul Arbousse-Bastide (sociology), Claude Levi-Strauss (ethnology), Fernand Braudel (history), Pierre Monbeig (geography)... 
preconceived theoretical ideas. Sometimes they took on hypotheses which were quite original, at the time unthinkable elsewhere. An example is the valorization of racial interbreeding, linked to the search for a Brazilian identity and contrary to all the anthropological conceptions of the times. ${ }^{44}$

\section{COMPARATIVE ELEMENTS ON THE CONDITIONS OF RECEPTION AND OF INTEGRATION OF MODERN SCIENCE}

\section{1. The persistence of a living traditional science}

The ways in which modern science is diffused and received differ strongly depending on the nature of the host society. We instanced this in previous pages by comparing categories of country historical situations. There are the 'new' countries, composed of recently transplanted European social groups (like Australia), then those which have had a 'colonial' science which, through many different complex, obstructive or favourable, processes, has changed gradually on contact with modern science both before and after political independence (the Latin American countries and the United States fit this pattern, with varying fortunes ${ }^{45}$ ), and finally countries which had an ancient (sometimes extremely ancient) scientific tradition, whether moribund or strongly surviving. The latter situation proves to be of considerable significance for the ways in which modern science is encountered, even if this tradition is in decline or deteriorated by comparison with its bygone splendour (as in the case of the Arab-speaking countries). This is because there remains, albeit as vestiges, activities and an intellectual and cultural ground which make up field lines that structure the reception of the incoming science (and that, in a preliminary period, condition the encounter). ${ }^{46}$

Through historical studies conducted on such countries as China, Korea, Japan, India, Iran, Egypt, Tunisia, Turkey (and the Moslem countries in general), ${ }^{47}$ this category of situations indicates that a wide variety of cases and factors contributed to the conditions of encounter, reception and assimilation of modern European science and that these conditions were always specific.

In the countries of Islamic culture mentioned, the schools, which pass on the tradition, and the national language, vector of that tradition, are strong factors in determining the ways in which the modern science of European origin is introduced and 'transferred'. The mediators of this modern science were

\footnotetext{
44 Those of Lucien Levy-Bruhl and Bronislaw Malinowski as well: see Queiroz [1989].

45 One of the roots of the different ways science acclimatized in Latin America and North America is that the latter (Canada and the US) consisted originally of settlement colonies, the former of colonies for exploiting resources.

46 This aspect is given a clear analysis by Rashed [1992].

47 See the articles by Roshdi Rashed, Ekmeleddin Ihsanoglu and Alberto Elena in Petitjean et al. [1992] and Ihsanoglu [1992]. The case of Pre-Colombian civilizations, in stark contrast, independently of the fact of knowing what their sciences were like, represents cultural genocide, the result of which is a discontinuity between the ancient tradition and the science that was destined to become installed.
} 
representatives of the classical tradition (in its vestiges). This has at least been shown for the exact sciences, with this peculiarity: their tradition, even partly forgotten, was attached to the 'classical science' in which modern European science finds its roots.

Similar lessons, but still specific, are offered by other case bearing on different places and circumstances. For traditional, still-viable networks of learning, the reception of imported knowledge occurs through its integration into the pre-existing body of knowledge concerning the corresponding field (see an account of the introduction of Western medicine into late XIXth century China, in Yunnan. ${ }^{48}$ Specialists of history of sciences in the Asian countries have been able to detect that juxtaposition of the two bodies of knowledge - traditional and modern - especially where medicine or technology are concerned, often succeed either in throwing into relief the continuing interest of the former, or in amalgamating the two in one original syncretic ensemble. ${ }^{49}$

Japan put up three types of response to interactions between its own scientific tradition and the one coming from Western Europe, over three centuries from the XVIIth to the XXth. The first contacts were made in the XVIIth century, but this period, a time when a local scientific tradition was blossoming, was marked by a desire for isolation and the rejection of external influences (missionaries were expelled, for example). The XVIIIth century saw a certain opening out to the western world (especially through the intermediary of Dutch merchants), and the spread of scientific books translated into Chinese by the Jesuits. Medicine and botany were particularly appreciated. However, European science did not really penetrate until the second half of the XIXth century, at the time of the rapid modernization which was a feature of the 1868 Meiji restoration. If, for instance, the mathematics arriving from the West were rapidly assimilated, spread and cultivated, the existence of a well-developed, vibrant traditional school (the Wasan tradition) before the Meiji era was certainly not unrelated. ${ }^{50}$ However, another factor of success lies in the link between mathematics and their applications and, in this case, in the needs for military technology of the Japanese government of the day.

This diversity of responses to Western science depending on the circumstances gives the opportunity to raise a certain number of problems, which are structural so to speak and which condition the reception or, to put it better perhaps, the appropriation of this science. Among these problems, we will mention: the role of the traditional system in which civil servants have been educated, the conflicts between traditional practices and imported knowledge; the dynamics of the relationships that are forged between the knowledge learnt and the Western notion of science (for example, in the case of Japan, a transition has been recognized from the traditional interest in medicinal plants to the development of botany as a separate field of learning); the setting up of new educational institutions; the importance of translations into local vernacular

\footnotetext{
48 Article by Elisabeth Hsii in Science et empires [1990].

${ }^{49}$ Articles by Fumihiko Satofuka (on Japan), by Sunil Sondhi (on India) and by Bing Wang (on China) in Science et empires [1990].

${ }^{50}$ See the articles by Shokichi Ianaga, and by C. Jami in Petitjean et al.. [1992].
} 
languages in the tansmission of scientific knowledge (see, on this aspect, the considerable role played, in India, by translations and by networks for scientific diffusion in the national languages: Urdu, Bengali or Sanskrit ${ }^{51}$ ); the effect of linguistic questions; the distribution of books, and so on. ${ }^{52}$ An aspect whose importance cannot be overestimated concerns teaching; in order successfully to naturalize modern science and technology, a radical reform of the education system will have been needed (see, for example, the case of Egypt in the second half of the XIXth century ${ }^{53}$ ).

\section{2. Science, the elite and the State}

The success of the 'transfer' of modern science into a given country or area (Japan of the Meiji era, Egypt of Mehemet Ali, Republican Mexico of Porfiro Diaz $^{54}$ ) owes much to the determination of the elite and those in power locally. In Latin America, the universities and research institutions in the modern sense appeared, only after the national independences and impelled by a genuine movement in this direction. ${ }^{55}$ In China, in spite of previous contacts with Europe, the mathematics originating from the West only really began to be adopted in the XIXth century, ${ }^{56}$ owing to the movement towards westernization and reforms. This, in other words, resulted from a decision by the national authorities, in effect for practical and especially military reasons. The scientific knowledge imported was ranked lower in importance than philosophy or ethics. This attitude to science as just a tool limited the extent to which it penetrated and it was not really until the XXth century that mathematics, to keep this field as example, was to be assimilated. Because all this happened against the background of the country's submission to Western powers, the progress of the situation of science in China, from the first era to the last can be summarized as "from decline to alienation". 57

In all the cases examined, the incorporation of modern science has been a crucial factor in the construction or modernization of States, whether integration has happened through the activity of its scientific leading figures or by the foundation and development of education and research structures and institutions. In the nationalist movements of America, the role played by physicists and

\footnotetext{
${ }^{51}$ Habib [1985], Krishna [1993] and articles in Petitjean et al. [1992], Raina [1992, 1993, 1996a and b]. See, for Sri Lanka, the contribution by Soma Kuma Mendis to TWAS [1990].

52 Hallewell [1982].

${ }^{53}$ Rashed [1992].

54 Cf. the articles by R. Rashed and by Juan José Saldana in Petitjean et al. [1992]. In Mexico, the analogy of the system of science and the State with the one prevailing in France during the Revolution and in XIXth century concerned the ideological aspect more than the scientific policy.

55 Cf. Paty [1992b].

56 The Jesuits, in the XVIIth century, had brought in modern knowledge of astronomy and mathematics, useful for the reform of the Chinese calendar and this was in a period when ancient Chinese mathematics was seeing a revival. However, the importation remained strictly limited and fragmentary, and moreover involved only a small elite.

57 Contribution by C. Jami in Petitjean et al. [1992]; by Annick Horiushi and C. Jami in Science et empires [1990].
} 
naturalists is well known. José Bonifacio, geologist and politician in Brazil, José Celestino Mutis and his botany expedition across New Grenada (present-day Colombia and Venezuela) ${ }^{58}$, have become symbolic in this respect. These scholars, however, inheritors of the ideas of the scientists of the Age of the Enlightenment, required by the young republics for tasks of leadership, training and government, let their time be taken up and were no longer available for developing the sciences. In the end, in spite of science's early involvement in the constitution of political states, projects or programmes for science went unheeded most of the time.

The integration of modern science and the contribution to its rapid expansion varied with the disciplines, often chosen for pragmatic reasons. But to be successful and to effect a real transfer, this process should not be restricted to education and technology, and efforts are required to promote research activities. Case studies show that absence of this dimension lead to scientific dependence.

The importance, in the development of a country's own research base, of the activity of the natural history museums has been evidenced. ${ }^{59}$ In general, the process of institutionalization of sciences results from an evolution, marked out by rhythms and structures, which are diverse depending on the situations, in one place shifting from the needs of education to those of research, ${ }^{60}$ in others stimulating the foundation of modern universities, possibly favoured by the existence of international academic, scientific networks. ${ }^{61}$

\subsection{Diverse comments}

Modern science is not just diffused untouched into the peripheral and dependent countries. It is also enriched: some of its disciplines are born or are modified from knowledge related to these lands (the building up of ethnology, ${ }^{62}$ tropical medicine ${ }^{63}$, egyptology, of a particular technology, ${ }^{64}$ fundamental changes in the natural sciences, ${ }^{65}$ etc.). Not counting the reverberating influences of scientific expeditions and voyages on the awakening of an interest within the 'centres' or metropoles to the peripheral countries, especially in philosophical and

\footnotetext{
58 Concerning José Bonifacio, see Tarquinio de Souza [1945]. José Celestino Mutis y Bossio (1732-1808) is the author of a monumental work Flora de la real expedicion botanica del Nuevo Reino de Granada in 51 volumes: see also Mutis [1983].

59 Notably in Brazil and other Latin American countries. Cf. Margaret Lopes in Petitjean et al. [1992], Domingues [1995], Figueroa [1995].

60 See, for example V. Krishna, D. Raina \& I. Habib, in Petitjean et al. [1992].

${ }^{61}$ See the case of the University of Sao Paulo, in Brazil of the 1930s: cf. Petitjean, in Hamburger et al. [1996]).

${ }^{62}$ Queiroz [1889]. See above.

63 Article by A. M. Moulin in Petitjean et al. [1992] and contribution by M. Worboys in Science and empires [1990].

${ }^{64}$ See for example Gama [1979].

${ }^{65}$ See for example the rebounding effects of 'science of the Empire', in India, on entomology in England (Worboys [1979]).
} 
political ideas, such as the unity of the human race or the vocation of knowledge towards universality. 66

Transformations of entire branches of science such as geography, botanic, zoology, as well as the constitution of new disciplines such as anthropology, are often associated with the work of scientific travellers, individuals as well as participants in organized expeditions. Or they can be related to the setting-up of scientific councils linked with colonization projects (three are well known, in the XIXth century: those on Egypt and Mexico, initiated by France, and the Comision Cientifica del Pacifico, set in place by Spain ${ }^{67}$ ). These last ones have undoubtedly added to modern science's corpus of knowledge, in particular by making an inventary of new fields of study. But whether they favoured transfers of knowledge, and contributed in a way or another to the technical and social development of the countries concerned is still controversial $^{68}$, as the precise influence in this respect is difficult to evaluate, being in the best of the cases rather indirect and long delayed. Such eventual effects may have been induced in the further developments in the context of national independencies, being eventually kept hidden by that context.

The theme of the scientific travel is particularly interesting from the viewpoint that preoccupies us here. Those of the XVIIIth (even the end of the XVIIth) to the XIXth centuries not only contributed to the construction of modern science, but had an impact in the countries involved on their scientific awakening (but also in the spread of ideas, such as those of the Age of the Enlightenment or of the French Revolution, which would constitute a factor in the formation of a national and social conscience, notably in the countries of Spanish America on their way to independence). The relative success of these travels or expeditions on the scientific front depended directly on the motives and the approaches taken to achieve them. When science was (at best) only a secondary objective (in the case of ventures led by merchants, corsairs, militaries, or politicians), the results obtained in this order were usually of second-rate interest or quality. On the opposite the outcome of expeditions conducted with an expressly scientific objective, even when mixed with other motives, yielded highly valuable

66 We can mention Michel de Montaigne (Les Essais, 1572-1592), Jean-Jacques Rousseau (Discours sur l'origine de l'inégalité des hommes, 1753, L'Emile, 1762), Denis Diderot (Supplément au voyage de Bougainville, 1773), Guillaume-Thomas Raynal (Histoire philosophique et politique des établissements et du commerce dans les deux Indes, 1770),.... See also, for instance, Franco [1937].

67 As is well known, the Egypt expedition gave rise to a work of monumental proportions, $L a$ description de l'Egypte, published in 1809-1830 under the auspices of the French Academy of Sciences. See Description de l'Egypte [1809-1828], Laissus [1998]. A lively account of the venture, readable by a wide public, has been published recently (Solé [1998]). Concerning the Commissions of the Pacific and Mexico, see L. Lopez-Ocon, contribution in Science et empires [1990].

68 Outre les références de la note précédente, signalons : Fernandez [1956], Hernandez-Saenz [1997], Bourguet [1998]. Les uns nient qu'un transfert aient eu lieu, tandis que les autres font état de certaines réalisations. Le fait qu'un développement effectif ait été possible grâce à la volonté de libres administrations gouvernementales n'interdit pas des préparations, comme dans le cas colonial ordinaire. 
contributions; a striking feature of these scientific ventures is that they were strongly interdisciplinary. ${ }^{69}$

The voyage of La Condamine and Bouguer to South America, from 1735 to 1743 , has rightly remained famous. Sent by the French Academy of Sciences to measure one degree of meridian at the Equator and to check the bulge of the Earth's sphere that fitted Newton's theory of gravitation, the group of scientists obtained considerable significant results, not only for physics but also in other areas of natural sciences. ${ }^{70}$ The Spanish expedition realized at the end of the XVIIth century towards Patagonia and the West coast of South America has also stayed in the annals. Two other great voyages turned out to be decisive for knowledge of South America: that of Alexandre von Humboldt and Aimé Bonpland in the northern part and Alcide d'Orbigny's venture to the southern part. ${ }^{71}$

It would also be instructive to examine the theme of travellers who went in the opposite direction, hailing from the 'peripheral' or other extra-European countries to visit Europe. ${ }^{72}$ Other cases from more ancient times can be added on to such investigations, which would perhaps bear witness to the perpetual quality of this curiosity regarding Nature and Man, in the desire to know and to communicate. There exists perhaps, underlying this dimension of opening out, a profound search for universality, as represented by the Portuguese poet Luiz Camoens in his song Lusiadas, transcending the particular instance of Vasco de Gama's voyage to express "the symbolic adventure of human communication at the universal scale" and undertake "the verification, experimental so to speak, that humanity is one, everywhere similar and different."73

\section{ELEMENTS OF CONCLUSION.}

In this paper, we have intended to draw some lessons of the rather new chapter of history of sciences that deals with the establishment of science (in the sense we understand it today), in countries commonly called 'in the process of development' and that have been, in a recent past, the object of colonization or domination by European nations. Our purpose was not to bring new data, and we have restricted ourselves to case studies that have been presented in the literature, without claiming exhaustivity, but trying to take into account recent significant publications in various languages.

We wanted first to examine whether and how these data and these researches modify history of sciences, the discipline itself and its object. We have

\footnotetext{
${ }^{69}$ See the articles by Manuel Vegas-Velez, J. Pimentel and by J. de la Sota Rius, in Science et empires [1990].

${ }^{70}$ Lafuente \& Delgado [1984].

71 The works published by these scientific explorers are well known. On these expeditions, see for example, Minguet [1969], Lafuente \& Delgado [1984], J. de la Sota Rius, article in Science et empires [1990].

72 Efendi [1757], edition 1981.

${ }^{73}$ Lourenço [1988].
} 
given some details about the broadening of both. Then, taking a comparative point of view on various situations and contexts, we have sketched to inventory some major themes of this relatively specific field of the history of sciences, trying to put in evidence differences, convergences, perhaps common features and eventually some constants. What characterizes, actually, the field in question, is the diversity of the conditions and circumstances of the implantation in these countries of modern science, such as it has developed since XVIIth century in European countries. These circumstances go from its encounter with the inheritance of ancient cultural and scientific traditions (of which it was itself tributary in some cases) up to mere and direct import, in the case of "new countries'.

This variety, that requests differential case studies, does not mean a dispersion of divided factual descriptions. To grasp some unity in this diversity, or at least to relate some elements, it is not necessary to resort to ambitious totalizing explanatory models, always schematic and aiming to illustrate a priori theses more than to discern and to understand. The most reliable method is indeed comparative analysis, that requires, for sure, an ability to unveil the sensitive and significant conceptual elements underlying the descriptive data. These conceptual elements are of two kinds: some are relative to scientific contents, others to historical contexts. Their structural conjunction in the above evoked situations and problems contributes to enrich our conception of a social history of science that takes fully in account the specificity of science (or the sciences) and the dimension of history. Although embedded in the context of the social history, the notion of science as body of knowledge remains aimed at ideas and at practices connected to these ideas, these relationships playing in the two senses, and ideas being themselves connected with representations of the world.

In evidencing factors that favour the assimilation (or better: the appropriation) of scientific knowledges, we are opportunately remembered how much the latter, even with an abstract form, are unseparable from a cultural compost and that their implantation depends on volontary interest from inviduals as well as from societies. In a word, science is a kind of a plant, related to an environment, that needs appropriate cares and adequate plans for transportation and implantation. (It is a plant of reason with universal vocation, and about this universality and the questions it raises, the studies of this historical domain still have much to teach ${ }^{74}$ ).It is by no means a ready made technical objet for mere consume.

This again opportunately recalls us that science is thought and that its social aspects and utility have as their only primary source the intelligence of subjectivities, these forming the tissue of the societies. All these lessons on science are adequate to make people rediscover what might have been forgotten under the 'power of science' in contexts of dependency : for the subjective man, that is for everybody, science (the science he can get at, when it springs out in his mind) is not power, but freedom, in the same sense as it is freedom to make a full use of one's own reason. But the subsequent (social) transformations that make

${ }^{74}$ Cf. Paty [1997, 1999]. 
power, eventually oppression, from it are not of a different kind than those that make power, or oppression, from human relations.

The lessons that one can already draw fom the comparative studies concern therefore not only history of science, in its peculiarity and in its relation to general history, but epistemology as well, by those aspects that are relative to science contents at the level of their elaboration, their transformation, their communication and their appropriation. They concern also the philosophy of knowledge, requested to take into account the effective reality of science, as activity of thought and as social practice.

\section{BIBLIOGRAPHY}

Alfonso-Goldfarb, Ana Maria \& MaiA, Carlos A. eds. [1996]. História da ciência: o mapa do conhecimento (America 500 anos), Coleção América 92: Raízes e trajetorias, vol. 2, Rio de Janeiro: Expressão e Cultura / São Paulo : EDUSP.

ALVAREZ-PELAES, Raquel [1993]. La conquista de la naturaleza americana, Madrid : CSIC.

d'Ambrosio, Ubiratão ed. [1989]. Anais do Secundo Congresso LatinoAmericano de Historia da Ciência e da Tecnologia, Sâo Paulo: Nova Stella/EDUSP.

ARBOLEDA, Luis Carlos \& OSORIO, Carlos eds. [1997]. Nacionalismo e internacionalismo en la historia de las ciencias y la tecnología en America latina, Cali (Colombia) : Universidad del Valle.

BASSALLA, George [1967]. The spread of western science, Science 156, pp. 61622.

BourgueT, Marie-Noëlle et. al., éd. [1998]. L'invention scientifique de la méditerranée, Paris : EHESS.

Chatelin, Yvon \& Bonneuil, Christophe éds. [1996]. Nature et environnement (collection Les Sciences hors d'occident au XXè siècle, R. Waast ed, vol.3), Paris : ORSTOM.

COlCIENCIAS ed. [1994]. Francisco Joseph de Caldas y Thenorio (1768-1816), Bogotá : Molinos Velasquez.

Cueto, Marcos [1989]. Excellencia cientifica en la periferia. Actividades cientificas e investigación biomédica en el Perù, 1890-1950, Lima: GRADE/CONCYTEC.

DEL RIO, Andrès Manuel [1795-1805]. Elementos de Orictognosia, 2 vols., Zùniga y Ontiveros, Mexico : vol. 1, 1795 ; vol. 2, 1805. Reimpression fac-simile, edited with an introductory study by Raúl K. Kogan, Universidade aut6noma, Mexico, 1992.

DelaHAYE, Hubert \& JAMI, Catherine eds. [1993]. L'Europe en Chine. Interactions scientifiques, religieuses et culturelles aux XVII et XVIII siècles. 
(Acts of the Colloquium of Fondation Hugot, 14-17 october 1991, Paris, Collège de France), Mémoires de l'Institut des Hautes Études Chinoises, vol. 34.

DELAPORTE, François [1989]. Histoire de la fièvre jaune. Naissance de la médecine tropicale, Paris : Payot.

DENIS, Gilles [1996]. Les voyageurs naturalistes français en Colombie ou comment les voyages ont participé à la construction de la science, Paris: Muséum national d'histoire naturelle, 1996.

DESCRIPTION DE L'EGYPTE [1809-1828]. La Description de l'Egypte ou recueil des observations et des recherches qui ont été faites en Egypte pendant l'expédition de l'armée française, 1rst ed., 9 vols. and 11 vols. of plates, Paris, 1809-1828; 2nd ed., 26 vols. and 11 vols. of plates, Paris : Panckoucke, 18211830.

DIAS, Elena, TEIXERA, Yolanda \& VESSURI, Hebe [1983]. La ciencia periférica. Ciencia sociedade en Venezuela, Caracas : Monte Avila.

Diez Torre, Alejandro R., Mallo, Tómas \& Fernandez, Daniel Pacheco eds [1995]. De la Ciencia Illustrada a la Ciencia Romántica, Madrid : Doce Calles.

Domingues, Heloisa Maria Bertol [1995]. Ciência, um caso de política : as relações entre as ciências naturais e a agricultura no Brasil Império, Tese de doutorado, Universidade de São Paulo. (A detailed summary has been published by the author in Resgate, revista de cultura (Campinas, Brésil), nº 7, dec. 1997, pp. 121-126).

DROUIN, Jean-Marc [1989]. De Linné à Darwin : les voyageurs naturalistes, in Serres, Michel (éd.), Eléments d'histoire des sciences, Paris : Bordas.

EFENDI, Mehmed [1757]. Le paradis des infidèles. Relation de Yirmisekiz Çelebi Mehmed efendi, ambassadeur ottoman en France sous la Régence, traduit de l'ottoman par Julien-Claude Gallland, Paris. New ed. with intr. and notes by Gilles Veinstein, Paris : Maspero, 1981.

FARRINGTON, Benjamin [1944]. Greek science. Its meaning for us. New ed., UK : Penguin books, 1953.

FERNANDEZ DEL CASTILlO, Francisco [1956]. Historia de la Academia Nacional de Medicina en Mexico, Mexico : Editorial Fournier.

FERrAZ, Márcia Helena Mendes [1997]. As ciências em Portugal e no Brasil (1772-1822) : o texto conflituoso da Química, São Paulo : Educ/Fapesp.

FigueroA, Silvia F. de M. [1995]. Ciência na busca do Eldorado: a institutionalsação das ciências geológicas no Brasil (1808-1907), Tese de doutorado, Universidade de São Paulo.

Foglia, V. [1971]. Bernardo Alberto Houssay (1887-1971), Acta physiologica latino-ainericana 21, pp. 267-285.

FRANCO, Affonso Arino de Mello [1937]. O indio brasileiro e a Révolução francesa. As originas brasileias da teoria da bondade natural, Rio de Janeiro: José Olympio.

GAILLARD, Jacques [1989]. La science du tiers monde est-elle visible?, La Recherche 20, n²10, mai, pp. 636-640. 
GAMA, Ruy [1979]. Engenho e tecnologia (tese, 1979), Sâo Paulo: Duas Cidades, 1983.

- [1987]. A tecnologia e o trabalho na história, São Paulo : Nobel/Edusp.

- ed. [1993]. Ciência e técnica. Antologia de textos históricos, São Paulo: Queiroz.

HABIB, Irfan [1985]. Institutional efforts : popularization of science in the mid nineteenth century, Fundamenta scientiae 6 ( $\left.\mathrm{n}^{\circ} 4\right)$, pp. 299-312.

HABIB, Irfan \& RAINA, Dhruv eds. [1999], Situating the History of Science, New Delhi : Oxford University Press.

HALLEWELL, Laurence [1982]. Books in Brazil. A history of the publishing trade, Metuchen (N.J.) and London : Scarecrow press.

Hamburger, Amelia I., Dantes, Maria A., PAty, Michel \& Petitjean, Patrick [eds., 1996]. A ciência nas relações Brasil-França (1850-1950), São Paulo: EDUSP.

HEADRICK, Daniel R. [1981]. The Tools of Empire. Technology and European Imperialism in the Nineteeth Century, UK : Oxford Univ. Press.

HernandeZ-SAEnZ, Luz M. [1997]. Learning to Heal, New York : Peter Lang.

INKSTER, Ian [1985]. Scientific enterprise in historical context, Social studies of science 15, pp. 677-706.

IHSANOGLU, Ekmeleddin [1992]. Transfer of Modern Science \& Technology to the Muslim World, Istambul.

JAMI, Catherine, HASHIMOTO, Keizo \& SKAR, Lowell eds. [1995]. East Asian Science: Tradition and Beyond. Papers from the Seventh International Conference on the History of Science in East Asia. Kyoto, 2-7 August 1993, Osaka : Kansai University Press.

KRISHNA, V. V. ed. [1993]. SS Bhatnagar on Science, Technology and Development, 1938-54, New Delhi : Wiley Eastern Ltd.

KUMAR, Deepak ed. [1991]. Science and empires: essays in Indian context, New Delhi : Anamika Prakashan.

- [1995]. Science and the Raj, 1857-1905, New Delhi : Oxford University Press.

LAFuente, Antonio \& Delgado, Antonio [1984]. La geometrización de la Tierra. Observaciones y resultados de la Expedición géodésica hispano-francesa al Virreynato del Perù (1735-1744), Madrid: Consejo Nacional de Investigaciones Cientificas.

LAFuente, Antonio \& CATAla, José Sala eds. [1992]. Ciencia colonial en America, Madrid : Alianza Universal.

LAFUENTE, Antonio \& SALDAÑA, Juan José [1987]. Nuevas tendencias en la historia de las ciencias, Madrid : CSIC.

LAISSUS, Yves [1998]. L'Egypte, une aventure savante, 1798-1801, Paris: Fayard. 
MACLEOD, Roy [1982]. On visiting the moving metropolis : reflections on the architecture of imperial science, Historical Records of Australian Science 5, $\mathrm{n}^{\circ} 3$, pp. 1-16.

MACLEOD, Roy ed. [1988]. The Commonwealth of science: ANZAAS and the scientific enterprise in Australia, 1888-1988, Melbourne: Oxford University Press.

MingueT, Charles [1969]. Alexandre de Humboldt, historien et géographe de l'Amérique espagnole (1799-1804), Paris, : Institut des Hautes Etudes d'Amérique Latine.

Motoyama, Shozo ed. [1994]. Tecnologia e industrialização no Brazil, São Paulo : UNESP.

MUTIS [1992]. Mutis y la real expedición botánica del nuevo Reyno de Granada, 2 vols., Bogotá : Villegas /Barcelona : Lundwerg.

NAKAYAMA, Shigeru [1987]. Periodization of the East Asian history of science, Revue de Synthèse 108, 4è série, n 3-4, july-dec., pp. 375-380.

Osorio, I. [1986]. Historia de las bibliotecas novohispanicas, México: Secretaria de Educación Pública.

PALladino, Paolo \& WORBOYS, Michael [1993]. Science and imperialism, Isis, 84, pp. 91-102.

PATY, Michel [1990]. L'analvse critique des sciences, ou le tétraèdre épistémologique (sciences. philosophie, épistémologie, histoire des sciences), Paris : L'Harmattan.

- [1992b]. L'histoire des sciences en Amérique latine, La Pensée, n²88-289, pp. $21-45$.

- [1996a]. Sobre o estudo comparativo da história da difusão e da integração das ciências, in Alfonso-Goldfarb \& Maia [1996], pp. 837-880.

- [1996b]. A recepção da relatividade no Brasil e a influença das tradições científicas europeias, in Hamburger, Dantes, Paty, Petitjean [1996], pp. 143-181.

- [1996c]. Remarques sur la production sociale des sciences et la question de la vérité, in Malet, Emile \&Le Bras, Hervé (éds.), Science et démocratie. Penser le XXIè siècle, Paris : Editions Passages, pp. 185-219.

- [1997]. L'idée d'universalité de la science et sa critique philosophique et historique, in Arboleda \& Osorio [1997], p. 57-89. Also, Asclepio (Madrid), 49 (2), 1997, pp. 5-43.

- [1998]. Universality of Science : Historical Validation of a Philosophical Idea, in Habib \& Raina [1998], pp. 303-324.

Petitjean, Patrick éd.[1996]. Les sciences coloniales. Figures et institutions, Paris : ORSTOM.

Petitjean, Patrick, Jami, Catherine \& Moulin, Anne-Marie eds. [1992], Sciences ad Empires, Dordrecht : Kluwer. 
PolANCO, Xavier ed. [1990]. Naissance et développement de la science-monde. Production et reproduction des communautés scientifiques en Europe et en Amérique latine, Paris : La Découverte.

PYENSON, Lewis [1985a]. Functionaries and Seekers in Latin America: Missionary Diffusion of the Exact Sciences, 1850-1930, Quipu, 2, pp. 387-422.

- [1985b]. Cultural Imperialism and Exact Sciences : German expansion, 19001930, New York.

- [1989a]. Empire of Reason: Exact Sciences in Indonesia, 1840, Leiden : Brill.

- [1989b]. Pure Learning and Political Economy: Science and European Expansion in the Age of Imperialism, in Wisser et al [ 1989], pp. 209-278.

QUEIROZ, Maria Isaura Pereira de [1989]. Desenvolvimento das clênclas sociais na America latina e contribuição européia : o caso brasileiro, Ciencia e Cultura (SBPC, São Paulo), 41 (n 4, april), pp. 378-388.

Quevedo, Emilio, VASCO, Carlos, OBREgon, Diana \& OROZCO, Luis Enrique eds. [1993]. Historia social de la ciencia en Colombia, Bogotá : Colciencias, 10 vols.

QUIPU [1992]. Historia de la tecnologia autóctona, Quipu (Mexico) 9, n² (mayoagosto), pp. 131-254.

RaHMAN, Abdur ed. [1984]. Science and Technology in Indian culture. A Historical Perspective, New Delhi : Nistads.

RAINA, Dhruv [1992]. Mathematical Foundations of a Cultural Project or Ramachandra's Treatise "Through the Unsentimentalised Light of Mathematics", Historia Mathematica 19, pp. 371-384.

- [1993]. The Unfolding of an Engagement : "The Dawn" on Science, Technical Education and Industrialisation: India, 1896-1912, Studies in History 9, n ${ }^{\circ}$, pp. 87-117.

- [1996a]. Reconfiguring the Centre: The Structure of Scientific Exchanges between Colonial India and Europe, Minerva 34, 1996, 161-176.

- [1996b]. The Moral Legitimation of Modern Science : Badralok Reflexions on Theories of Evolution, Social Studies of Science, 26, pp. 9-42.

RASHED, Roshdi [1978]. La notion de science occidentale, in Forbes, E.G. (ed.), Human Implications of Scientific Advance, Edinburgh, 1978, pp. 45-54.

- [1987]. La périodisation des mathématiques classiques, Revue de Synthèse 108, 4è série, n 3-4, july-december, 349-360.

- [1992]. Science classique et science moderne à l'époque de l'expansion de la science européenne, in Petitjean, Jami, Moulin [1992], pp. 19-30.

Reingold, N. \& RothenberG, M. [eds., 1987]. Scientific colonialism : a crosscultural comparison, Washington : Smithsonian Institution Press.

SALDAÑA, Juan-José [1989]. La influencia de la Revolución francesa en la modernisación cientifica de México, Arbor (Madrid), n 527-528, pp. 135-158.

- ed. [1992]. Las origenes de la ciencia nacional, Mexico : Cadernos de Quipu 4. 
SALIBA, George [1987]. The Role of Maragha in the Development of Islamic Astronomy: a Scientific Revolution Before the Renaissance, Revue de Synthèse 108, 4è série, n³-4, july-december, pp. 361-374.

Sangwan, Satpal [1991]. Science, Technology and Colonissation. An Indian Experience, 1757-1857, New Delhi : Anamika Prakashan.

SARTON, George [1931]. Introduction to the history of science, 3 vols. in 5 tomes, Baltimore : Wilkins ; New York : Krieger Hutington, 1975.

SCHREDER-GRUDEHUS, Brigitte [1966]. Caractéristiques des relations scientifiques internationales, 1870-1914, Cahiers d'histoire mondiale 10, pp. 161177.

SCHRÖDINGER, Erwin [1950]. Are There Quantum Jumps ?, The British Journal for the Philosophy of science, $3,1952, \mathrm{n}^{\circ} 10$.

SCIENCE ET EMPIRES [1990]. Unpublished essays presented to the International Congress Science et empires, Paris : CNRS.

SCLIAR, Moacyr [1992]. Sonhos tropicais, São Paulo : Companhia das Letras.

SOLE, Robert [1998]. Les savants de Bonaparte, Paris : Seuil.

StEPAN, Nancy [1976]. Beginnings of Brazilian Science : Oswaldo Cruz Medical Research and Policy, New York, 1976.

TARQuinio DE SouZA, Octávio [1945]. José Bonifacio, Rio de Janeiro : José Olympio ; 4th ed., Sâo Paulo : Itatiaia/EDUSP, 1988.

VARGAS, Milton ed. [1994]. História da técnica e da tecnologia no Brasil, São Paulo : Unesp.

VESSURI, Hebe ed. [1987]. Dinámica cientifica en la periferia, 2 vols, San José de Costa Rica, 1987.

WAAST, Roland éd. [1996]. Les sciences hors d'Occident au XXè siècle, 6 vols., ORSTOM, Paris, 1996.

WISSER, R.P.W., Bos, H.J.M., PALM, L.C., SNELDERS, H.A.M. eds. [1989]. New Trends in the History of Science, Amsterdam : Rodopi.

Worboys, Michael [1979]. Science and British Colonial Imperialism, 18951940, Ph D. Thesis (unpublished), University of Sussex, 1979. 